\title{
KAJIAN DAMPAK PEMBANGUNAN EMBUNG KONSERVASI MENDEKATI ZERO RUN OFF DALAM PENGENDALIAN BANJIR KAWASAN
}

\author{
Prasoni Agung, Bakhtiar AB, R. Didin Kusdian \\ Universitas Sangga Buana \\ Prasoni.agung@gmail.com
}

\begin{abstract}
ABSTRAK
Embung adalah suatu bangunan konservasi air yang berbentuk kolam yang digunakan untuk menampung air hujan dan air limpasan sekitar untuk keperluan cadangan air pada saat musim kemarau. Tetapi embung dapat juga dikembangkan sebagai sarana kolam retensi untuk pengendalian banjir dalam skala kecil, diharapkan air hujan yang jatuh dikawasan pemukiman tersebut dapat ditampung di embung ini, sehingga kawasan ini dapat disebut sebagai kawasan zero runoff, dimana tidak terdapat limpasan air yang keluar ke hilir dari kawasan ini. DAS Cipamokolan bagian hulu tergolong tidak sering banjir, tetapi kejadian luar biasa terjadi pada bulan Maret 2018, dimana pada saat itu terjadi banjir bandang beserta lumpur yang menerjang pemukiman. DAS Cipamokolan sampai dengan titik tinjau ini luas DASnya sebesar $6,705 \mathrm{~km}^{2}$, berdasarkan analisa frekuensi curah hujan rencana adalah 10 tahunan sebesar 129,7 mm dengan debit puncak banjir sebesar 32,084 $\mathrm{m}^{3} /$ det, Rencana pengendalian banjir Cipamokolan ini adalah dengan membuat embung di hulu sehingga limpasan air ke arah hilir dapat dikurangi. Dan analisa reduksi banjir dihitung dengan menggunakan penelusuran banjir melalui embung/waduk dengan menggunakan software HECHMS 3.5. dan dapat mereduksi puncak debit banjir sebesar 7,60\% sampai 34,76\% dari debit puncak kondisi eksisting. Kapasitas alur sungai Cipamokolan di ruas ini adalah sebesar 28,681 $\mathrm{m}^{3} /$ det. Dengan kapasitas sebesar ini, maka kondisi dengan adanya embung ini akan dapat menampung debit dengan kala ulang 10 tahun, dimana dengan adanya embung maka debit puncak banjir dari sebesar $32,084 \mathrm{~m}^{3} / \mathrm{det}$ dapat menjadi sebesar $24,441 \mathrm{~m}^{3} / \mathrm{det}$. Sehingga dapat dikatakan bahwa dengan adanya embung ini kondisi zero run off masih belum bisa dicapai, tetapi debit puncak banjir dapat tereduksi, sehingga diharapkan dapat mengurangi dampak banjir yang mungkin terjadi.
\end{abstract}

Keyword: Embung konservasi, zero run off, pengendalian banjir, Daerah Aliran Sungai

\section{PENDAHULUAN}

\section{Latar Belakang Penelitian}

Perkembangan suatu wilayah kota dalam bidang ekonomi akan menyebabkan wilayah tersebut menyebabkan pertumbuhan terhadap pemukiman penduduk yang semakin besar. Kebutuhan akan tempat tinggal ini juga telah dimanfaatkan dengan baik bagi pengusaha bidang perumahan. Sehingga banyak sekali wilayah yang masih kosong atau lahan pertanian misalkan pinggiran kota yang berubah fungsi menjadi wilayah pemukiman.

Perubahan fungsi lahan ini tentu akan menimbulkan dampak perubahan hidrologi dan hidrogeologi pada wilayah tersebut dan juga wilayah di daerah upstream dan downstreamnya. Kasus yang sering kita jumpai adalah wilayah pemukiman ini rentan terhadap bahaya banjir, baik yang berupa banjir akibat luapan sungai atau saluran drainase lainnya, maupun banjir akibat aliran air tidak dapat terbuang ke saluran drainase 
atau sungai, ataupun banjir kiriman dari wilayah di hulunya.

Alih fungsi lahan yang semakin meningkat menyebabkan semakin berkurangnya Ruang Terbuka Hijau (RTH) dan berkurangnya area resapan air khususnya di daerah perkotaan. Hal ini disebabkan oleh pesatnya peningkatan jumlah penduduk di perkotaan yang mengakibatkan semakin meningkatnya kebutuhan ruang dan sumberdaya. Berkurangnya area resapan air akan mempercepat terjadinya aliran permukaan (run-off) dan memicu terjadinya banjir (Kodoatie, 2002).

\section{Identifikasi Masalah}

Zero runoff atau dapat diartikan bahwa pada suatu wilayah/kawasan, maka air hujan yang jatuh di wilayah tersebut akan dimanfaatkan semaksimal mungkin untuk keperluan wilayah atau kawasan itu. Konsep ini merupakan salah satu aspek dalam Program Pengembangan Kota Hijau.

Untuk mencapai zero run off ini, maka air hujan dalam wilayah pengembangan ini harus dikelola. Prinsip pengelolaan air hujan pada suatu wilayah pengembangan perumahan diharapkan dapat dilakukan dengan:

1. Memaksimalkan pemanfaatan air hujan

2. Memaksimalkan infiltrasi air hujan,
3. Menahan air hujan sementara waktu untuk menurunkan limpasan

Kajian pembangunan embung sebagai sarana untuk retensi air ataupun detensi dapat dipertimbangkan dalam pengembangan kawasan permukiman ini. Sehingga diharapkan dalam suatu wilayah pemukiman tidak akan terjadi aliran limpasan yang besar pada saat hujan yang dapat membahayakan daerah di hilirnya.

\section{Rumusan Masalah}

Permasalahan yang akan ditinjau dalam kajian ini adalah sebagai berikut:

1. Apakah zero run off itu dan bagaimana untuk dapat mencapai kondisi zero run off ini pada suatu wilayah perumahan/pemukiman?

2. Bagaimanakah dapat disusun suatu pedoman praktis dalam pengembangan embung konservasi suatu pemukiman agar dapat mencapai kondisi zero run off?

\section{Maksud dan Tujuan Penelitian}

Maksud penelitian ini adalah dalam rangka mengkaji pembangunan embung konservasi sebagai salah satu solusi pengendalian banjir dalam kawasan pemukiman.

Tujuan penelitian ini adalah untuk mendapatkan pedoman praktis dalam pembangunan embung konservasi

Manfaat Penelitian 


\section{Manfaat Ditinjau Akademik}

Manfaat penelitian ini secara akademik adalah dapat memberikan kajian yang terpadu dalam rangka mengurangi dampak banjir terutama dalam suatu kawasan perumahan dengan menerapkan konsep zero run off salah satunya dengan pengembangan embung konservasi.

\section{Manfaat Ditinjau Terhadap Praktisi}

Manfaat penelitian ini adalah dapat memberikan gambaran mengenai pembuatan embung konservasi dalam rangka menuju zero run off dalam suatu lingkup perumahan, serta dapat memberikan pedoman praktis pembuatan embung konservasi untuk wilayah perumahan lainnya.

\section{Hipotesis}

Debit limpasan yang terjadi dalam suatu DAS merupakan fungsi dari besarnya hujan yang terjadi dan kondisi DAS dimana hujan tersebut jatuh. Semakin tinggi hujan maka debit debit limpasan semakin tinggi. Dan semakin jelek kondisi DAS dimana kondsi tanah tidak dapat menginfiltrasi air hujan, maka debit limpasan akan semakin besar. Sehingga diperlukan suatu bentuk penampungan air sementara/retensi yang salah satunya adalah bentuk embung konservasi.

\section{Ruang Lingkup}

Ruang lingkup penelitian ini adalah meliputi hal hal berikut ini :
1. Studi pustaka

2. Pengumpulan data sekunder, meliputi Peta DAS, data curah hujan, data topografi, dan data sosial ekonomi

3. Pengumpulan data primer meliputi data aspirasi masyarakat mengenai pembangunan embung, data banjir dan data kerugian banjir

4. Analisa data meliputi perhitungan curah hujan dan debit banjir rencana

5. Perencanaan embung konservasi, analisa hubungan curah hujan dan dimensi/kapasitas embung yang dibutuhkan

6. Penulisan laporan hasil penelitian

\section{KAJIAN PUSTAKA}

\section{Tinjauan Umum}

Embung adalah suatu bangunan konservasi air yang berbentuk kolam yang digunakan untuk menampung air hujan dan air limpasan sekitar untuk keperluan cadangan air pada saat musim kemarau. Tetapi embung dapat juga dikembangkan sebagai sarana kolam retensi untuk pengendalian banjir dalam skala kecil, misalnya dalam suatu kawasan pemukiman.

\section{Analisa Hidrologi}

\section{Pemeriksaan Konsistensi Data}

\section{Hujan}

Pengujian konsistensi dengan metode RAPS (Rescaled Adjusted Partial Sums) menggunakan data dari stasiun itu sendiri, yaitu pengujian dengan komulatif 
penyimpangan terhadap nilai rata-rata dibagi dengan akar komulatif rerata penyimpangan kuadrat terhadap nilai reratanya.

\section{Analisis Distribusi Frekuensi}

Mengingat bahwa banjir merupakan salah satu kejadian ekstrem yang berhubungan erat dengan suatu sistem hidrologi, untuk mengetahui hubungan antara besaran kejadian ekstrem tersebut dan frekuensi kejadiannya diperlukan analisis frekuensi.

\section{Uji Kesesuaian Distribusi}

Untuk menentukan kecocokan (the goodness of fit) distribusi frekuensi empiris dari sampel data terhadap fungsi distribusi frekuensi yang diperkirakan dapat menggambarkan/ mewakili distribusi empiris tersebut, diperlukan pengujian secara statistik. Terdapat dua cara pengujian yaitu uji Chi Kuadrat (ChiSquare Test) dan uji SmirnovKolomogorov.

\section{Uji Chi Square}

Uji Chi-Kuadrat hanya efektif bila jumlah data pengamatan besar, karena sebelum dilakukan pengujian, data pengamatan akan dikelompokkan terlebih dahulu.

Uji ini dimaksudkan untuk melihat distribusi amatan apakah dapat dihampiri dengan baik oleh distribusi teoritis.

\section{Uji Smirnov-Kolmogorov}

Pengujian Kolmogorov - Smirnov dilaksanakan dengan cara menggambarkan distribusi empiris maupun distribusi teoritis pada kertas grafik probabilitas sesuai dengan distribusi probabilitas teoritisnya.

\section{Curah Hujan Wilayah}

Secara hidrologi, jenis curah hujan yang diperlukan untuk perencanaan pemanfaatan sumberdaya air dan pengendalian banjir adalah curah hujan rata-rata wilayah yang dinyatakan dalam $\mathrm{mm}$.

\section{Distribusi Hujan Jam Jaman}

Pada studi ini, metode yang akan digunakan adalah Metode Mononobe. Metode Mononobe pada dasarnya dikembangkan di Jepang oleh Dr. Mononobe. Intensitas hujan rata-rata dalam suatu waktu tertentu dihitung berdasarkan persamaan:

$$
\mathrm{I}=\frac{R_{24}}{24}\left(\frac{24}{t}\right)^{2 / 3}
$$

dimana:

I : intensitas curah hujan ( $\mathrm{mm} / \mathrm{jam})$

$\mathrm{t}:$ lamanya hujan (jam)

$R_{24}$ : curah hujan harian (mm)

\section{Penelusuran Banjir dan Debit}

\section{Banjir Rencana}

Piranti lunak Hydrologic Modeling System (HMS) dikembangkan oleh Hydrologic Engineering Center, United States Army Corps of Engineers. Model merupakan 
hasil penyempurnaan model matematik HEC-1 yang dirilis pertama kali pada tahun 1967. Dengan menggunakan bantuan HEC-HMS, pengguna diberikan kemudahan dalam melakukan permodelan analisis debit banjir berbasis Hidrograf Satuan (HS) pada suatu DAS, penelusuran banjir sepanjang saluran/sungai, kalibrasi dan verifikasi parameter kalibrasi. Selain HEC-HMS juga menawarkan kemampuan untuk melakukan simulasi perhitungan debit banjir multiplan-multiflood serta menginvestigasi suatu seri hasil analisis banjir untuk beberapa sub-area atau subDAS dengan karakteristik dan permodelan yang tersedia.

Adapun komponen model HEC-HMS yang digunakan untuk mensimulasikan respon hidrologi pada suatu DAS terdiri atas Basin Model, Meteorologic Model dan Control Specifications. Melalui Basin Model, pengguna mensimulasikan kondisi fisik DAS beserta elemen-elemen hidrologi terkait yang disajikan dalam Meteorologic Model. Sedangkan Control Specifications digunakan untuk mengatur data baik periode waktu (time period) dan interval waktu (time step) dari suatu simulasi.

\section{Konsep Pengembangan Kota Hijau}

1 Panduan Penyelenggaraan Program Pengembangan Kota Hijau, Kementerian Pekerjaan Umum Dan Perumahan Rakyat
Kota Hijau juga merupakan kota yang melakukan adaptasi dan mitigasi terhadap perubahan iklim. Pengembangan Kota $\mathrm{Hijau}^{1}$ juga berarti pembangunan manusia kota yang berinisiatif dan bekerjasama dalam melakukan perubahan dan prakarsa bersama seluruh pemangku kepentingan.

Undang-Undang Nomor 26 tahun 2007 tentang Penataan Ruang telah secara tegas mengamanatkan $30 \%$ dari wilayah kota berwujud Ruang Terbuka Hijau (RTH), yang terdiri dari $20 \%$ RTH publik dan $10 \%$ RTH privat. Pengalokasian 30\% RTH ini ditetapkan dalam Peraturan Daerah (Perda) tentang RTRW Kota dan RTRW Kabupaten.

Untuk mewujudkan kota hijau, P2KH menerapkan sub-sistem lingkungan kota yang diistilahkan dengan 8 (delapan) atribut Kota Hijau, yaitu perencanaan dan perancangan kota yang ramah lingkungan; ketersediaan ruang terbuka hijau; peningkatan peran masyarakat sebagai komunitas hijau; pengelolaan sampah ramah lingkungan; pengelolaan air yang efektif; penerapan sistem transportasi yang berkelanjutan; konsumsi energi yang efisien; dan bangunan hijau.

\section{Konsep Water Sensitive Urban Design (WSUD)}

Direktorat Jenderal Cipta Karya Direktorat Bina Penataan Bangunan, Jakarta, 2017 
Water Sensitive Urban Design (WSUD) ${ }^{2}$ merupakan salah satu bagian dari konsep pendekatan infrastruktur hijau. Tujuan dari pendekatan konsep ini untuk melakukan pendekatan perencanaan dan perancangan kota yang berhubungan dengan sumber air dan manajemen lingkungan serta meminimalisasi dampak yang ditimbulkan oleh keberadaan air di permukaan perkotaan.

Manfaat dari penerapan konsep Water Sensitive Urban Design dalam pengembangan suatu kawasan.

Konsep ini memiliki beberapa elemen penting, elemen paling penting tersebut yaitu pemanfaatan air kembali (water reuse) dan pengolahan air (water treatment). Air hujan dan air buangan merupakan salah satu air yang diperhatikan pada konsep ini. Pada praktiknya, konsep ini melihat pengelolaan air hujan dan air buangan sebagai suatu peluang dalam merancang suatu kota, bukan sebagai limbah. Elemen tersebut diturunkan kepada elemen rancang kota yang perlu diperhatikan dalam penerapan WSUD

\section{OBJEK DAN METODE}

\section{PENELITIAN}

Objek penelitian adalah Sungai Cipamokolan bagian hulu yang terletak di 6050'20"LS sampai 6054'08" LS dan

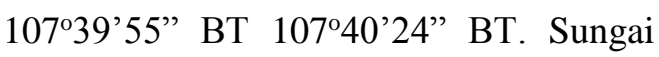

Cipamokolan ini terletak di wilayah Kecamatan Cimenyan Kabupaten Bandung dan Kelurahan Jatihandap Kecamatan Mandalajati Kota Bandung.

Metode penelitian ini adalah pengumpulan data primer melalui survei ke lokasi dan pengumpulan data sekunder untuk mendukung perencanaan embung konservasi.

Penelitian dilakukan di daerah DAS Cipamokolan hulu, dimana pada Maret tahun 2018 terjadi banjir bandang yang menyebabkan kerugian secara material yang cukup besar.

\section{HASIL DAN PEMBAHASAN}

\section{Kondisi Umum}

\section{Wilayah Administrasi}

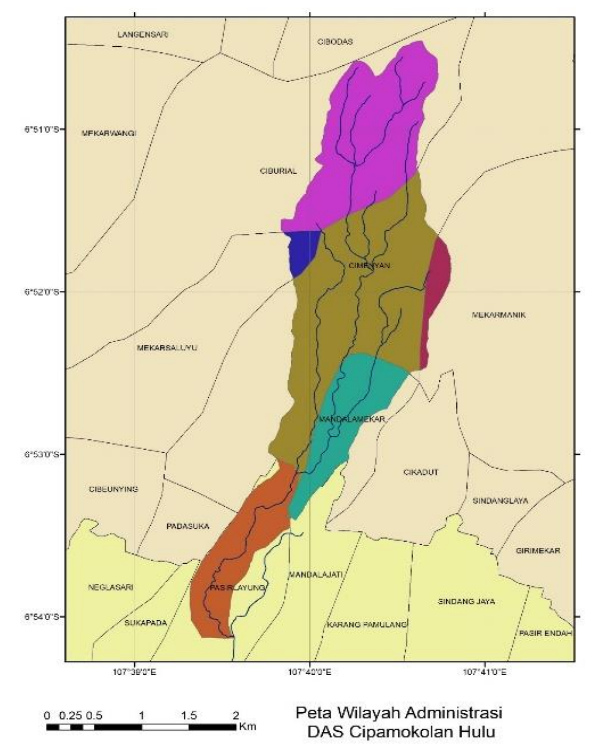

${ }^{2}$ Water Sensitive Urban Design in the UK Ideas Book, CIRIA. 2013. London 
Gambar 4-1 Peta Wilayah Administrasi DAS Cipamokolan Hulu

Adapun wilayah administrasi yang melingkupi lokasi penelitian di DAS Cipamokolan bagian hulu ini adalah berada di Desa Ciburial, Desa Mekarsaluyu, Desa Cimenyan, Desa Mandalamekar, Kecamatan Cimenyan Kabupaten Bandung dan Kelurahan Pasirlayung Kecamatan Cibeunying Kulon di Kota Bandung, seperti tampak pada Gambar IV.1.

\section{Kondisi Kependudukan}

Penduduk di DAS Cipamokolan bagian hulu adalah menurut data tahun 2018 sekitar 66.327 jiwa. Dimana pertambahan jumlah ini dari tahun ke tahun semakin besar.

\section{Kondisi Iklim dan Curah Hujan}

Kondisi iklim di lokasi pekerjaan berdasarkan data tahun 2018, suhu ratarata tahunan adalah $23,5^{\circ} \mathrm{C}$, Curah hujan bulanan tertinggi terjadi pada bulan Februari tahun 2008 sebesar 416,7 mm. Rata-rata kelembaban relatif yaitu 79,6\%.

\section{Tata Guna Lahan}

Penggunaan lahan di DAS Cipamokolan ini adalah sebagai lahan pertanian dan permukiman, dan sudah tidak terdapat hutan. Tingkat urbanisasi di Kota dan Kabupaten Bandung sangat tinggi terutama beberapa tahun terakhir ini yang menyebabkan munculnya berbagai permasalahan seperti lingkungan, transportasi, energi (listrik, air, dan lainlain), perumahan, dan lainnya. Permasalahan tersebut juga terjadi pada daerah bantaran beberapa sungai dan anak sungainya yang melalui Kota Bandung, termasuk diantaranya adalah DAS Cipamokolan.

\section{Data Teknis DAS Cipamokolan}

Sungai Cipamokolan termasuk salah satu anak sungai Sungai Citarum. Sungai Citarum bagian hulu mempunyai 12 (dua belas) anak sungai yang bermuara di badan Sungai Citarum secara keseluruhan, diantaranya Sungai Cihaur, Sungai Cikapundung, Sungai Cipamokolan, Sungai Cikeruh, Sungai Ciminyak, Sungai Cirasea, Sungai Cisangkuy, Sungai Citarik, dan Sungai Ciwidey.

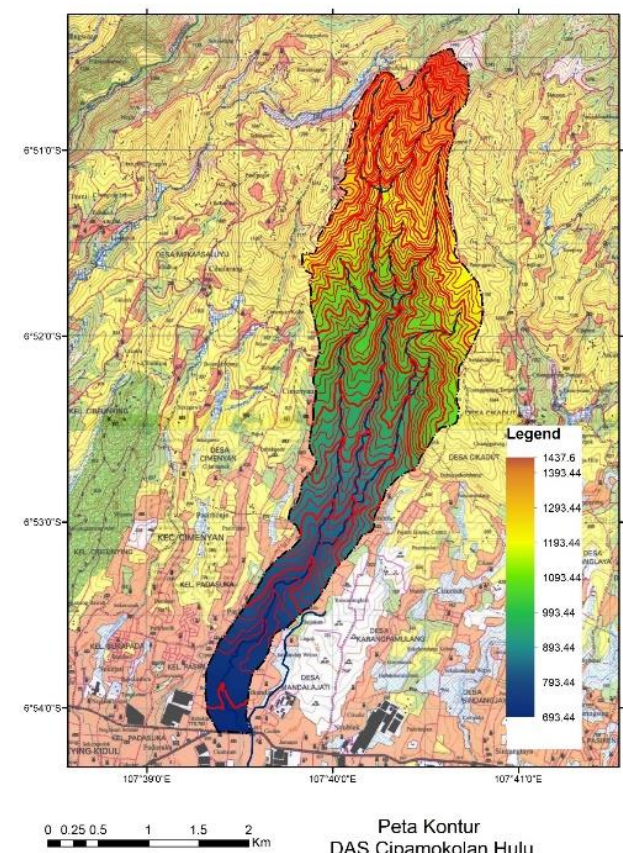


Gambar 4-2 Sungai Cipamokolan sampai dengan Titik Tinjau di Jalan AH Nasution

Sungai Cipamokolan ini bermuarakan di Sungai Citarum, dengan jarak dari titik tinjau di Jalan AH Nasution bekisar antara $11,915 \mathrm{~km}$, dengan kemiringan dasar sungai rata rata sekitar 0,00193 .

\section{Kejadian Banjir di DAS}

\section{Cipamokolan Hulu}

Kejadian luar biasa terjadi pada Bulan Maret 2018, dimana pada saat itu terjadi banjir bandang beserta lumpur yang menerjang pemukiman dan jalan yang berada di sepanjang Sungai Cipamokolan hulu ini terutama di daerah Jatihandap dan Cicaheum.

\section{Analisa Hidrologi debit Banjir}

\section{Rencana}

\section{Ketersediaan Data Hidrologi}

Data curah hujan yang mewakili adalah data-data dari stasiun terdekat dengan lokasi, yaitu Data curah hujan Stasiun Dago Pakar yang terletak pada $107^{0}$ 37'28,236” BT 60 51'42,552” LS untuk periode data tahun 2006-2018.

\section{Analisa Curah Hujan Rencana}

Sebelum dipakai untuk analisa, maka dilakukan uji kekonsistensian data untuk stasiun hujan Dago Pakar ini. Dari hasil uji konsistensi data dengan menggunakan metode RAPS diperoleh nilai parameter $\mathrm{Q} / \sqrt{\mathrm{n}}$ dan $\mathrm{R} / \sqrt{\mathrm{n}}$ sebesar masing masing
0,825 dan 1,167 , dmana masih lebih kecil dari nilai ambang batas untuk $\mathrm{Q} / \sqrt{ }_{\mathrm{n}}$ dan $\mathrm{R} / \sqrt{ } \mathrm{n}$ dengan nilai data $\mathrm{n}=12$, yaitu masing masing 1,086 dan 1,298.

Untuk menentukan tingkat kecocokan distirbusi frekuensi yang digunakan maka dilakukan uji Chi square dan Smirnov Kolmogorov untuk ketiga metode diatas,

Berdasarkan hasil uji kesesuaian distribusi frekuensi ini, maka akan dipilih metode Log Pearson Type III dimana nilai Chi Square 1,416 dan Smirnov Kolmogorovnya 0,1209 paling kecil diantara metode lainnya.

\section{Analisa Pengukuran Debit}

Untuk mengetahui kapasitas tampung Sungai Cipamokolan di titik tinjau Jl AH Nasution ini, maka dilakukan kajian bank full capacity, dengan data penampang sungai Cipamokolan di titik ini.

Lebar sungai $=3,5 \mathrm{~m}$, Kedalaman palung $=$ $3 \mathrm{~m}$

Kemiringan rata rata dasar sungai $=0,008$

Asumsi Koefisien Manning sungai $=0,035$

Dengan persamaan Manning diperoleh besarnya debit alur penuh adalah sebesar $28,68 \mathrm{~m}^{3} /$ det.

\section{Rencana Pengendalian Banjir}

Dalam merumuskan alternatif solusi terpilih pada lokasi/wilayah genangan banjir, harus mempertimbangkan faktor- 
faktor yaitu Topografi, Hidrologi, Sosekpol dan Pendanaan

Rencana pengendalian banjir Cipamokolan ini adalah dengan membuat tampungan di hulu sehingga limpasan air ke arah hilir dapat dikurangi. Salah satu cara yang dilakukan adalah dengan membangun beberapa series embung. Dimana embung ini didesain untuk dapat menampung air pada saat banjir dan dapat mengalirkan secara teratur ke arah hilirnya

Tabel 4-1 Rencana Lokasi Embung Konservasi

\begin{tabular}{|c|c|c|c|}
\hline No & $\begin{array}{c}\text { Embung } \\
\text { Di Desa, } \\
\text { Elv } \\
\text { A } \\
\text { Genangan }\end{array}$ & $\begin{array}{l}\text { Koordinat } \\
\text { Geografis }\end{array}$ & $\begin{array}{c}\text { Tinggi, } \\
\text { Luas } \\
\text { Genang } \\
\text { an,Vol }\end{array}$ \\
\hline 1. & $\begin{array}{l}\text { Mandala } \\
\text { Mekar } \\
+787 \\
4,302 \mathrm{Ha} \\
\end{array}$ & $\begin{array}{l}6^{\circ} 52^{\prime} \\
58,88^{\prime \prime} \mathrm{LS} \\
107^{\circ} 40^{\prime} \\
05,13^{\prime \prime} \mathrm{BT}\end{array}$ & $\begin{array}{c}11 \mathrm{~m} \\
1,188 \\
\mathrm{Ha} \\
48.750 \\
\mathrm{~m} 3 \\
\end{array}$ \\
\hline 2. & $\begin{array}{l}\text { Cimenyan } \\
+786 \\
1,116 \mathrm{Ha}\end{array}$ & $\begin{array}{l}6^{\circ} 52^{\prime} \\
58,65^{\prime \prime} \mathrm{LS} \\
107^{\circ} 39^{\prime} \\
58,25^{\prime \prime} \mathrm{BT}\end{array}$ & $\begin{array}{c}7 \mathrm{~m} \\
0,460 \\
\mathrm{Ha} \\
13.172 \\
\mathrm{~m} 3 \\
\end{array}$ \\
\hline 3. & $\begin{array}{l}\text { Pasir } \\
\text { Luyung } \\
+723 \\
6,049 \mathrm{Ha} \\
\end{array}$ & $\begin{array}{l}6^{\circ} 53^{\prime} \\
24,63^{\prime \prime} \mathrm{LS} \\
107^{\circ} 39^{\prime} \\
41,15 \mathrm{BT}^{\prime \prime}\end{array}$ & $\begin{array}{c}8 \mathrm{~m} \\
1,063 \\
\mathrm{Ha} \\
48.175 \\
\mathrm{~m} 3\end{array}$ \\
\hline 4. & $\begin{array}{l}\text { Pasir } \\
\text { Luyung } \\
+698 \\
6,313 \mathrm{Ha}\end{array}$ & $\begin{array}{l}6^{\circ} 53^{\prime} \\
39,46^{\prime \prime} \mathrm{LS} \\
107^{\circ} 39^{\prime} \\
30,10^{\prime \prime} \mathrm{BT}\end{array}$ & $\begin{array}{c}8 \mathrm{~m} \\
4,815 \\
\mathrm{Ha} \\
209.68 \\
7 \mathrm{~m} 3\end{array}$ \\
\hline
\end{tabular}

Pemilihan rencana lokasi embung konservasi ini cukup mengalami kesulitan akibat sudah padatnya pemukiman penduduk di sekitar Sungai Cipamokolan.
Adapun rencana lokasi embung ini adalah seperti Tabel 4-1.

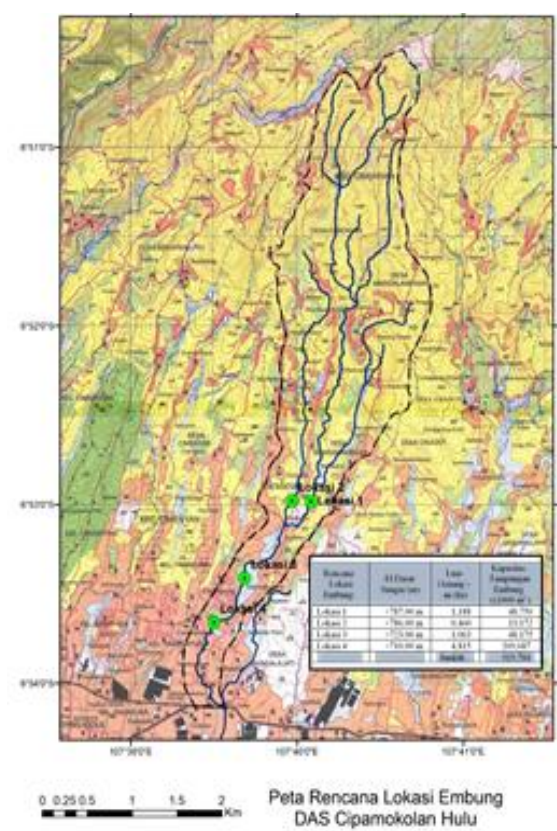

Gambar 4-3 Rencana Lokasi Embung Konservasi

Embung yang direncanakan ini tidak dimaksudkan untuk menyimpan air, tetapi untuk keperluan pengendalian banjir, sehingga untuk pengaliran air sehari hari dilakukan dengan membuat lubang outlet di badan embung.

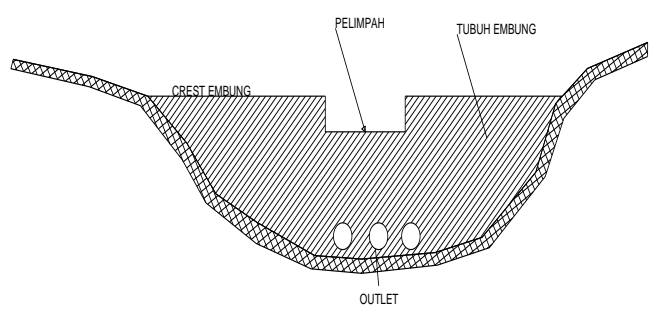

Gambar 4-4 Sketsa Penampang Melintang Rencana Embung

Berikut ini adalah rencana dimensi outlet, pelimpah dan embung yang paling optimal, yaitu dengan kriteria desain yang ada. 
Tabel 4-2 Rencana Dimensi Outlet, Pelimpah dan Embung

\begin{tabular}{|l|r|r|r|r|}
\hline & Embung 1 & \multicolumn{1}{|c|}{ Embung 2 } & Embung 3 & \multicolumn{1}{l|}{ Embung 4 } \\
\hline Elevasi dasar (m) & 787,00 & 786,00 & 723,00 & 710,00 \\
\hline Elevasi tebing max (m) & 800,00 & 793,00 & 731,00 & 718,00 \\
\hline Bangunan Outlet & 1 & 1 & 2 & 2 \\
\hline$\bullet \quad$ Jumlah & 788,00 & 787,00 & 724,00 & 711,00 \\
\hline$\bullet \quad$ Elevasi (m) & 0,25 & 0,16 & 0.25 & 0,25 \\
\hline$\bullet \quad$ Luas penampang outlet (m2) & & & & 3,00 \\
\hline Spillway & 2,00 & 1,00 & 2,00 & 2,2 \\
\hline$\bullet \quad$ Lebar (m) & 2,20 & 2,20 & 2,2 & 715,00 \\
\hline$\bullet \quad$ Koef Debit & 795,00 & 790,00 & 728,00 & 718,00 \\
\hline$\bullet \quad$ El. Crest Pelimpah (m) & 798,00 & 793,00 & 731,00 & 8,00, \\
\hline El. Crest embung (m) & 11,00 & 7,00 & 8,00 & 209,69 \\
\hline Tinggi Embung (m) & 48,75 & 13,17 & 48,18 & 1,06 \\
\hline Volume embung total & 1,19 & 0,46 & & \\
\hline x 1000 m ${ }^{3}$ ) & & & & \\
\hline Area (ha) & & & & \\
\hline
\end{tabular}

Sumber : Hasil Analisa, 2019

\section{Analisa Potensi Pengurangan Debit banjir}

Dalam analisa potensi pengurangan debit banjir dengan adanya embung ini akan dihitung dengen penelusuran banjir melalui waduk/embung yang dihitung dengan menggunakan software HECHMS 3.5

Skematik penyusunan model sungai Cipamokolan ini dapat dilihat pada gambar berikut ini.

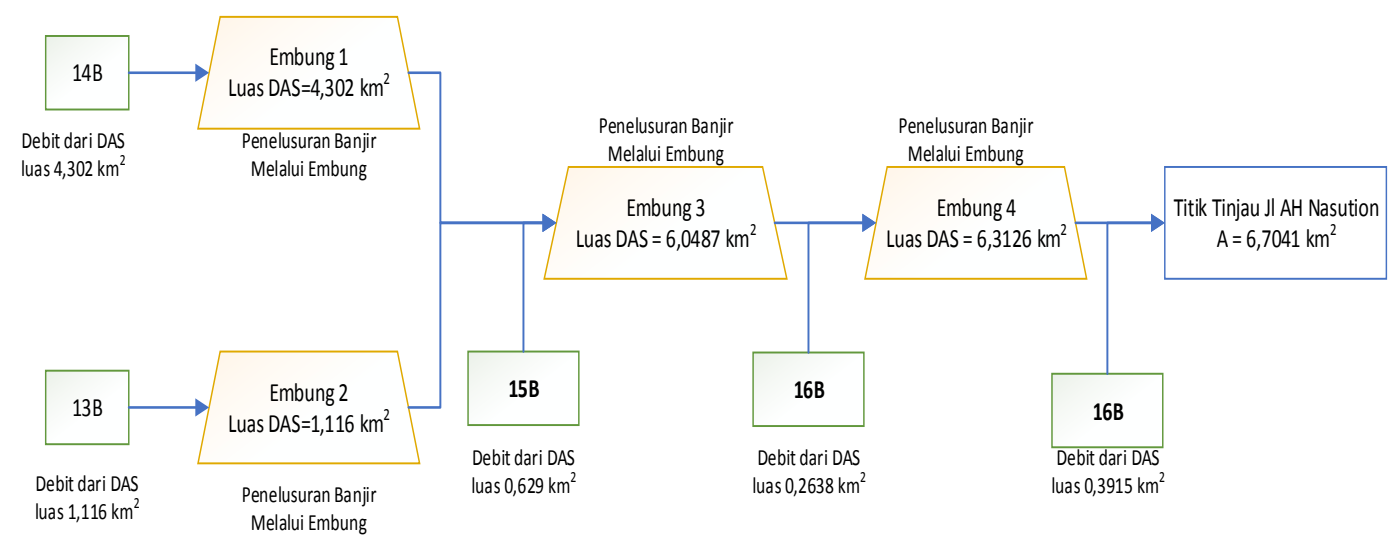

Gambar 4-5 Skematik Pemodelan Penelusuran Banjir dengan HECHMS 3.5 
Adapun besarnya debit untuk masing masing titik tinjau dan untuk masing masing besaran curah hujan yang dihitung

Tabel 4-3 Besarnya Debit pada Masing masing Titik Tinjau Embung untuk Kondisi Existing / Belum ada Embung

\begin{tabular}{|l|r|r|r|r|r|r|}
\hline \multicolumn{1}{|c|}{$\begin{array}{c}\text { Kala } \\
\text { Ulang }\end{array}$} & Tinggi Hujan & Embung 1 & Embung 2 & Embung 3 & Embung 4 & $\begin{array}{c}\text { J1 AH } \\
\text { Nasution }\end{array}$ \\
\hline & 5 & 0,198 & 0,160 & 0,536 & 0,695 & 0,861 \\
\hline & 10 & 0,419 & 0,215 & 0,822 & 0,989 & 1,163 \\
\hline & 40 & 1,379 & 0,433 & 2,071 & 2,264 & 2,477 \\
\hline Q2 & 50 & 4,445 & 1,085 & 6,018 & 6,289 & 6,612 \\
\hline Q5 & 106,96 & 18,293 & 3,900 & 23,683 & 24,377 & 25,117 \\
\hline Q10 & 129,7 & 23,451 & 4,926 & 30,159 & 31,054 & 32,084 \\
\hline Q25 & 163,07 & 31,139 & 6,466 & 39,797 & 40,999 & 42,476 \\
\hline Q50 & 190,89 & 37,612 & 7,761 & 47,906 & 49,371 & 51,237 \\
\hline Q100 & 229,09 & 46,560 & 9,549 & 59,194 & 60,940 & 63,350 \\
\hline Q1000 & 355,08 & 76,299 & 15,483 & 97,635 & 99,381 & 103,637 \\
\hline
\end{tabular}

Sumber : Hasil Analisa, 2019

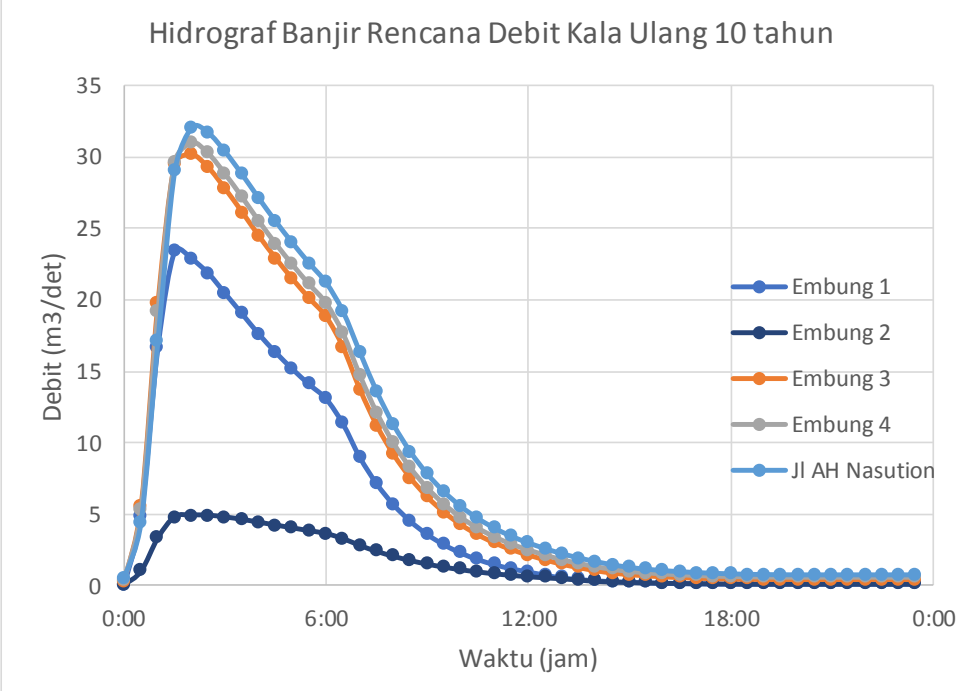

Gambar 4-6 Hidrograf Banjir Kondisi Eksisting 


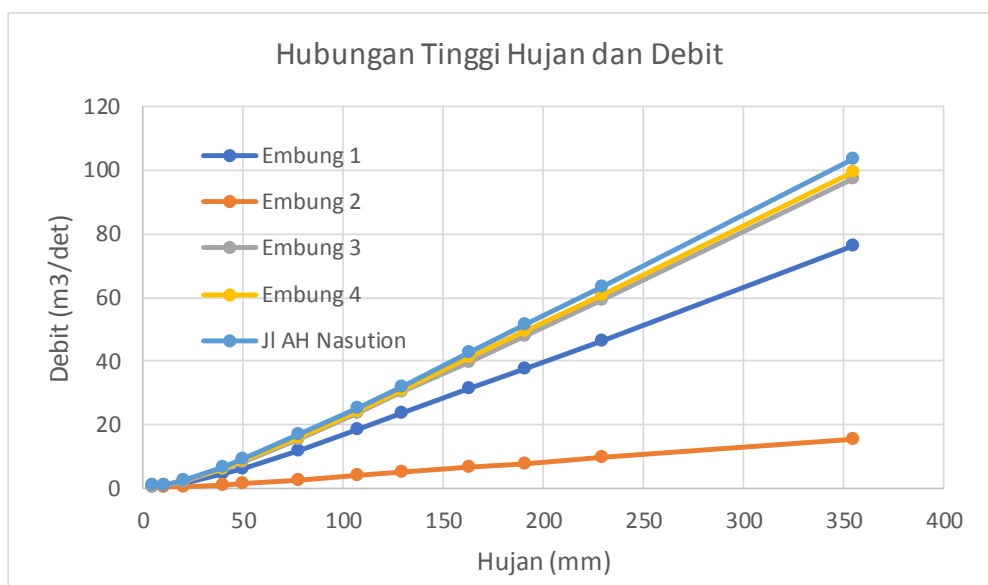

Gambar 4-7 Grafik Hubungan Besarnya Tinggi Hujan dan Debit Limpasan

Pemodelan untuk rencana embung dengan menggunakan HECHMS dapat digambarkan sebagai berikut:

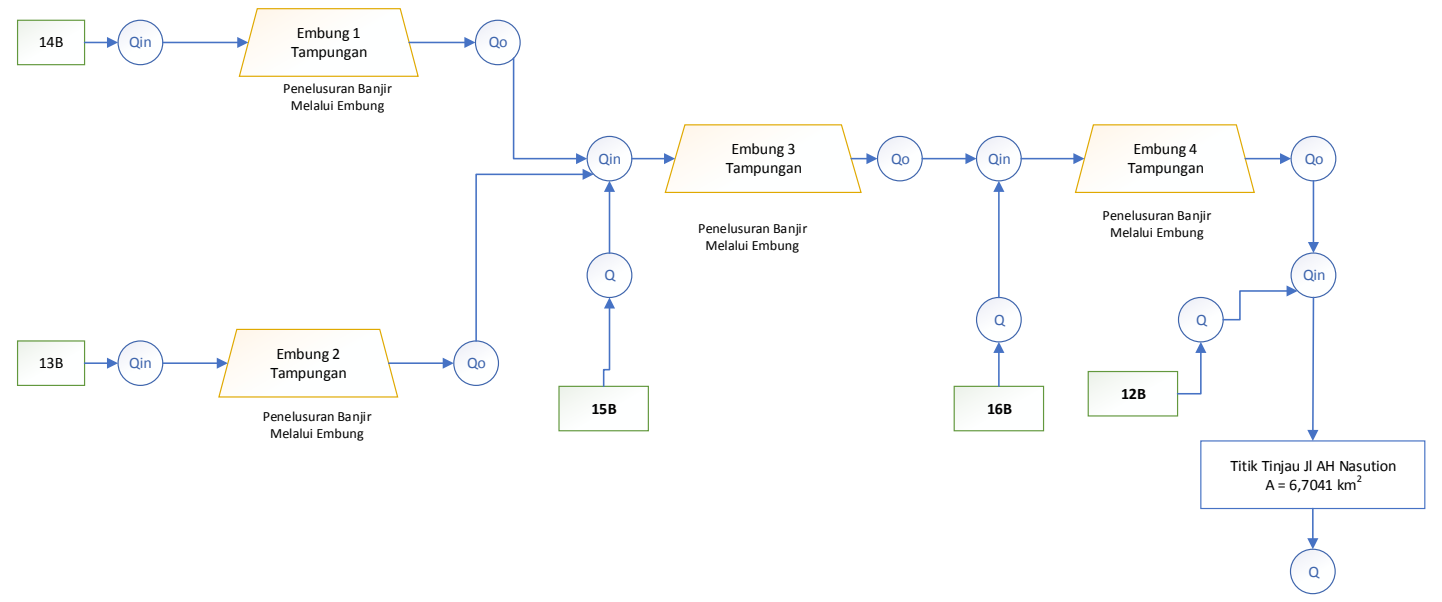

Gambar4-8 Skematik Debit Penelusuran Banjir dengan HECHMS 3.5

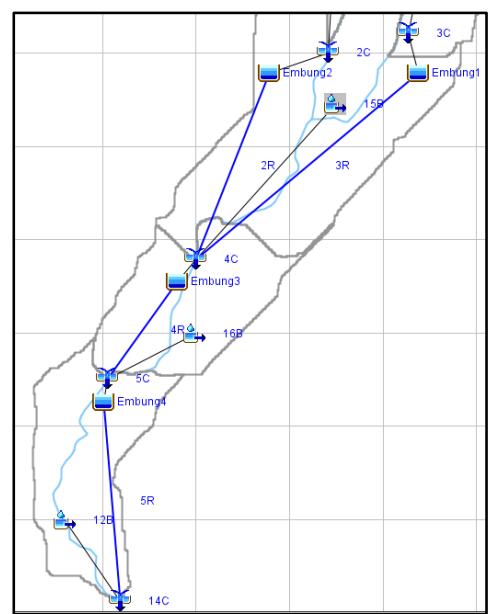

Gambar 4-9 Skematik Pemodelan Sungai Cipamokolan dengan adanya Embung
Dengan menggunakan software HECHMS maka dilakukan penelusuran banjir melalui embung ini. Dengan sebelumnya memasukkan data data teknis rencana embung seperti pada Tabel di atas. Kondisi yang disebutkan dalam tabel tersebut berdasarkan kondisi fisik di lokasi embung. Adapun hasil penelusuran banjir embung 1,2,3,4 dan kami tampilkan embung 4 


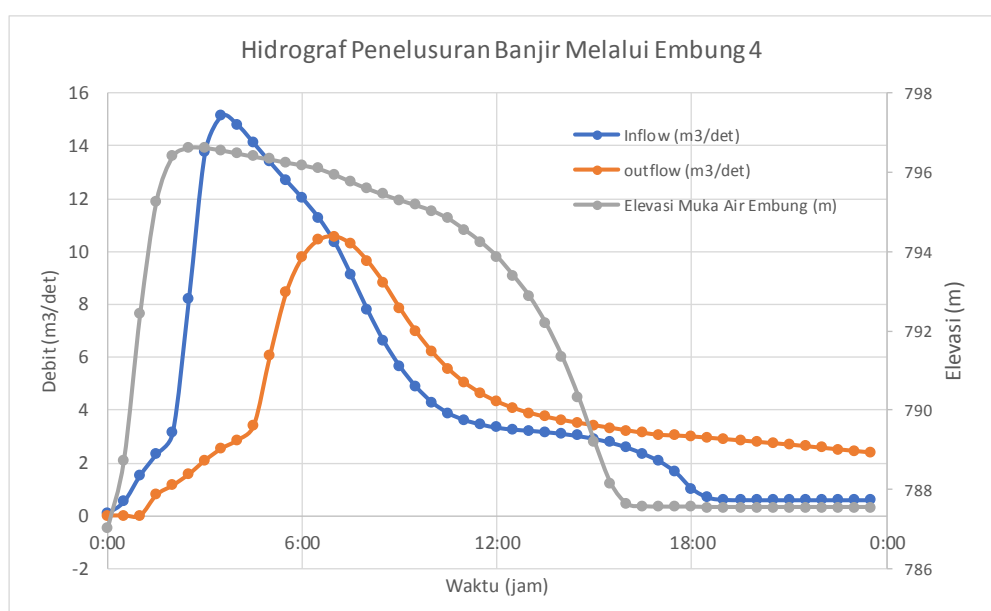

Gambar 4-10 Hidrograf Banjir Penelusuran Banjir Melalui Embung 4

Dari hasil penelusuran banjir ini tampak bahwa debit yang keluar melalui embung mengalami reduksi atau pengurangan, sehingga bisa mereduksi debit banjir Dan dengan kondisi ini diperoleh pengurangan reduksi debit banjir sebagai berikut

Tabel 4-4 Persentase Reduksi Debit Banjir di Titik Jalan AH Nasuiton

\begin{tabular}{|l|r|r|r|r|r|}
\hline \multirow{2}{*}{ Kala Ulang } & \multirow{2}{*}{$\begin{array}{c}\text { Tinggi Hujan } \\
(\mathrm{mm})\end{array}$} & \multicolumn{2}{|c|}{ Debit Banjir Maksimum (m3/det) } & \multicolumn{2}{c|}{ Reduksi Debit Banjir } \\
\cline { 3 - 6 } & 5 & Exisiting & Rencana Embung & m3 & \multicolumn{1}{c|}{$\%$} \\
\hline & 10 & 0,861 & 0,836 & 0,025 & $2,90 \%$ \\
\hline & 20 & 1,163 & 1,122 & 0,041 & $3,53 \%$ \\
\hline & 40 & 2,477 & 1,833 & 0,644 & $26,00 \%$ \\
\hline & 50 & 6,612 & 2,789 & 3,823 & $57,82 \%$ \\
\hline Q2 & 9,087 & 3,252 & 5,835 & $64,21 \%$ \\
\hline Q5 & 77,92 & 16,691 & 10,889 & 5,802 & $34,76 \%$ \\
\hline Q10 & 106,96 & 25,117 & 18,617 & 6,500 & $25,88 \%$ \\
\hline Q25 & 129,70 & 32,084 & 24,441 & 7,643 & $23,82 \%$ \\
\hline Q50 & 163,07 & 42,476 & 33,294 & 9,182 & $21,62 \%$ \\
\hline
\end{tabular}

Sumber : Hasil Analisa, 2019

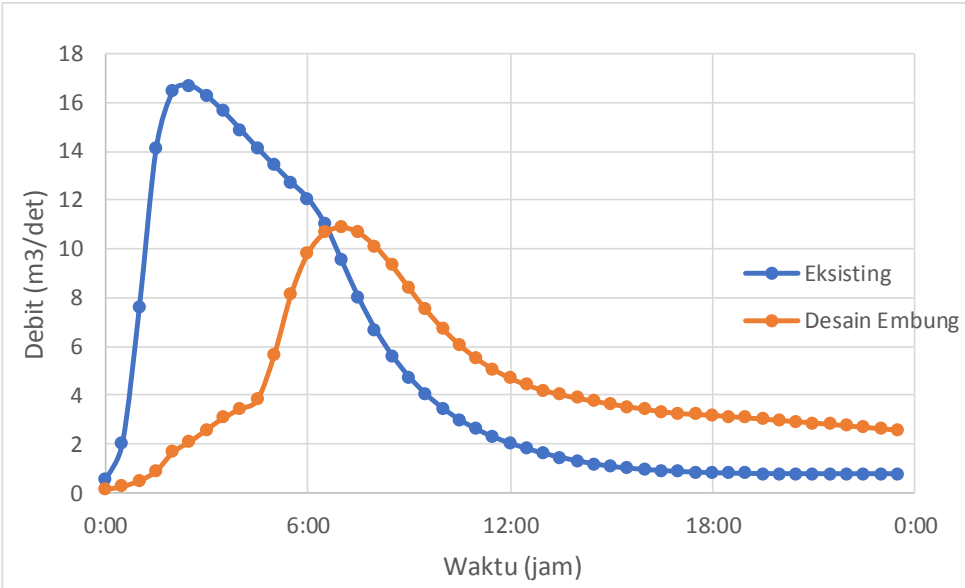

Gambar 4-11 Hidrograf Banjir di Titik Tinjau Jalan AH Nasution untuk Kondisi Debit Banjir kala Ulang 2 tahun 


\section{KESIMPULAN DAN SARAN}

\section{Kesimpulan}

Untuk mengurangi debit puncak banjir Sungai Cipamokolan, maka dibuat embung konservasi sebanyak 4 buah.

Dari hasil analisa penelusuran banjir ini, dapat disimpulkan bahwa kondisi maksimal yang dapat dikurangi dampak banjirnya adalah sampai dengan debit banjir dengan kala ulang 10 tahun, dimana dengan adanya embung maka debit puncak banjir dari sebesar $32,084 \mathrm{~m}^{3} /$ det menjadi sebesar 24,441 m3/det. Sehingga masih dapat ditampung oleh kapasitas tampung maksimum alur sungai Cipamokolan di titik tinjau Jl. AH Nasution yang sebesar $28,681 \mathrm{~m}^{3} /$ det.

\section{Saran}

Penelitian ini dilakukan sebagai gambaran bahwa embung dapat digunakan sebagai sarana pengendali debit banjir untuk mereduksi dan meyarankan untuk dibuat embung lebih banyak lagi supaya bisa mereduksi banjir lebih banyak

\section{DAFTAR PUSTAKA}

Kays, Barrett L. 2015. "Beyond Green LID Zero Runoff Strategies for Our Cities", Paper to International Low Impact Design Conference, American Society of Civil Engineers, Houston, TX

Kodoatie, R.J., dan Sugiyanto (2002) Banjir Beberapa Penyebab dan Metode Pengendaliannya Dalam Perspektif Lingkungan. Semarang: Pustaka Pelajar.

Kodoatie, Robert J., dan R. Sjarief (2010) Tata Ruang Air. Yogyakarta: Penerbit Andi.

Lampiran Peraturan Menteri Pekerjaan Umum Nomor 11 /PRT/M/2014 Tentang Pengelolaan Air Hujan Pada Bangunan Gedung Dan Persilnya, Kementerian Pekerjaan Umum, 2014

Pedoman Teknis Konservasi Air Melalui Pembangunan Embung, dalam https://bebasbanjir2025.wordpress.c om/teknologi-pengendalianbanjir/embung/, download 2018

Panduan Penyelenggaraan Program Pengembangan Kota Hijau, Kementerian Pekerjaan Umum Dan Perumahan Rakyat Direktorat Jenderal Cipta Karya Direktorat Bina Penataan Bangunan, Jakarta, 2017

Water Sensitive Urban Design in the UK Ideas Book, CIRIA. 2013. London 